\title{
Introduction
}

\section{Vanessa Davies}

This collected volume aids in the completion of the publication of George Reisner's excavations at Naga ed-Deir (see Map 1). This material was only partially published by Reisner during his lifetime due to both the intensity of his archaeological workload, which in the case of Naga ed-Deir resulted in a large number of excavated finds and human remains, and because of changes in his own career. From 1899-1905, Mrs. Phoebe A. Hearst supported Reisner's archaeological expedition to various sites in Egypt. Reisner directed excavations at Naga ed-Deir from February 1901 to March 1903, and Arthur C. Mace directed work at the site for Reisner from 1903 to 1905. Under Mace's direction, cemeteries $\mathrm{N} 2000$ and $\mathrm{N} 2500$ were excavated.

Cemeteries $\mathrm{N}_{2} 2000$ and $\mathrm{N} 2500$ are treated here in one publication (Figs. 0.1-0.2). The site was first visited in an official capacity by George Reisner on February 1, 1901 (Reisner vi). Reisner and his team had been working the nearby sites of el-Ahaiwah, Ballas, and Deir el-Ballas. The cemetery divisions

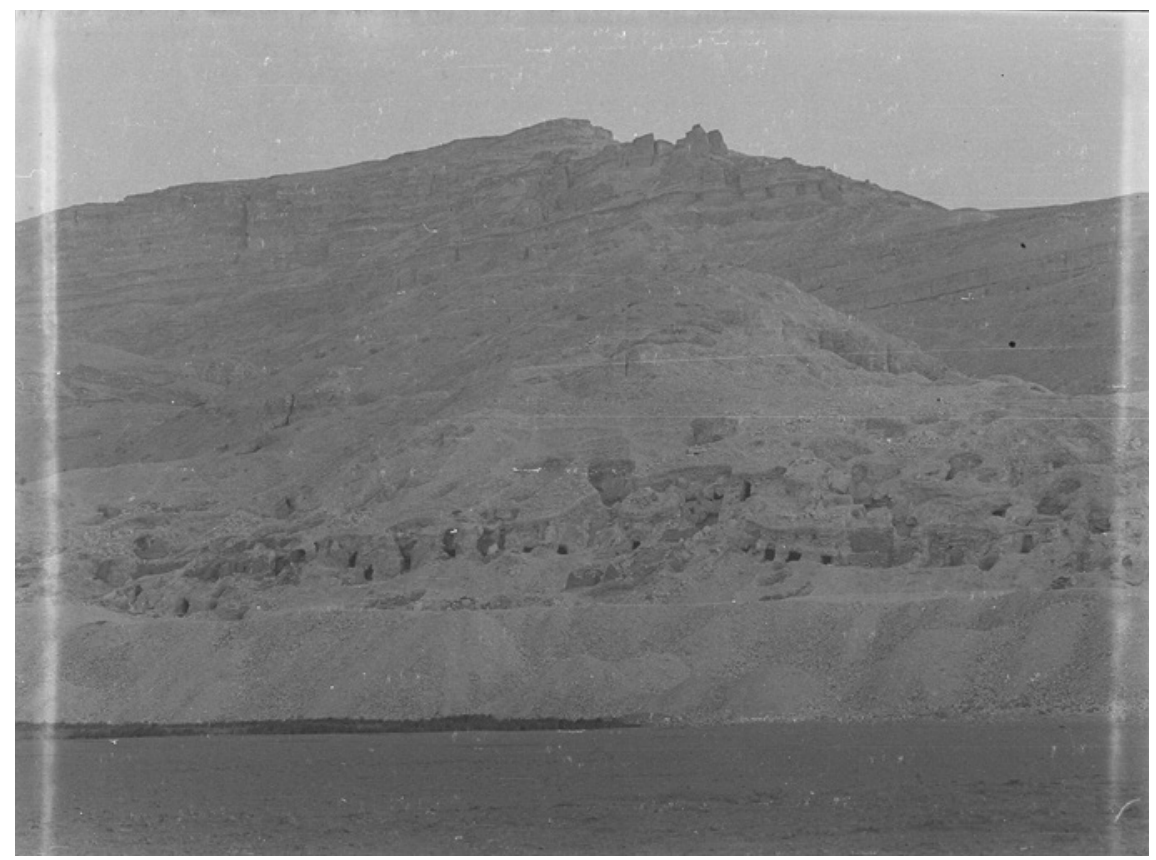

FIGURE 0.1 Slope of N 2000/N 2500 from the cultivation (NED-A-7672)

(C) VANESSA DAVIES, 2021 | DOI:10.1163/9789004396906_002

This is an open access chapter distributed under the terms of the CC BY-NC-ND 4.plicensese. Davies - 9789004396906 


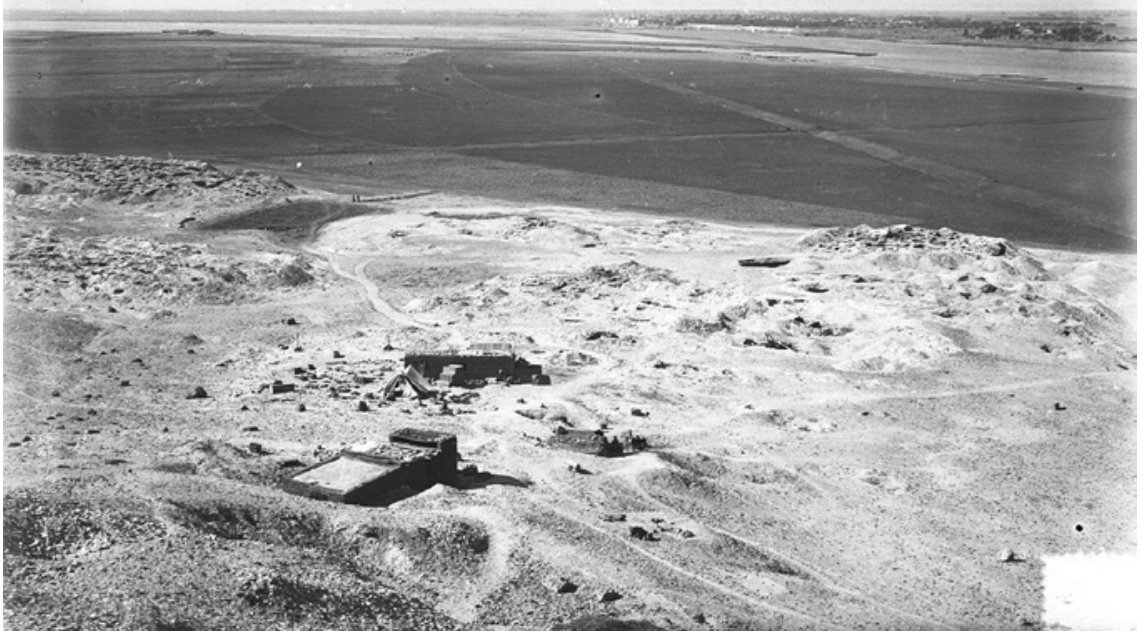

FIGURE 0.2 From the cliff above camp, N 2000/250o to the north, N 3000 , and N 1500 to the south (NED-B-2178)

that Reisner came up with were based on the topography of the landscape, rather than any certain chronological distinction between the burials. The core group of records from seasons $1903-1905$ consist of 368 pits (either with or without burials), 240 in Cemetery N 2000 and 128 in Cemetery N 2500. Of those, in Cemetery N 2000, 105 are First Intermediate Period/Middle Kingdom, 92 are Coptic, and 43 are empty. In Cemetery N 250o, 26 are First Intermediate Period/ Middle Kingdom, 58 are Coptic, and 44 are empty. An additional 7 records are Reisner's from preliminary work he did in the cemeteries in 1901.

This publication is based on the original records of excavation work that was done at Naga ed-Deir from the 1903 through the 1905 seasons under the patronage of Phoebe A. Hearst, directed by George Reisner, and headed by Arthur C. Mace (Fig. o.3). Other non-Egyptian team members were Albert M. Lythgoe and Frederick W. Green. In 1902, Reisner offered the anthropologist Grafton Elliot Smith some of the Coptic skeletons to study as part of his controversial theories regarding diffusion and race, theories that have been proven to be scientifically inaccurate (Challis 2013; Gange 2013). Smith's argument about diffusion rested on the premise that cultural markers, such as mummification, developed only once in human history, in this case, in Egypt, and from there were diffused throughout the world. His theory about race 


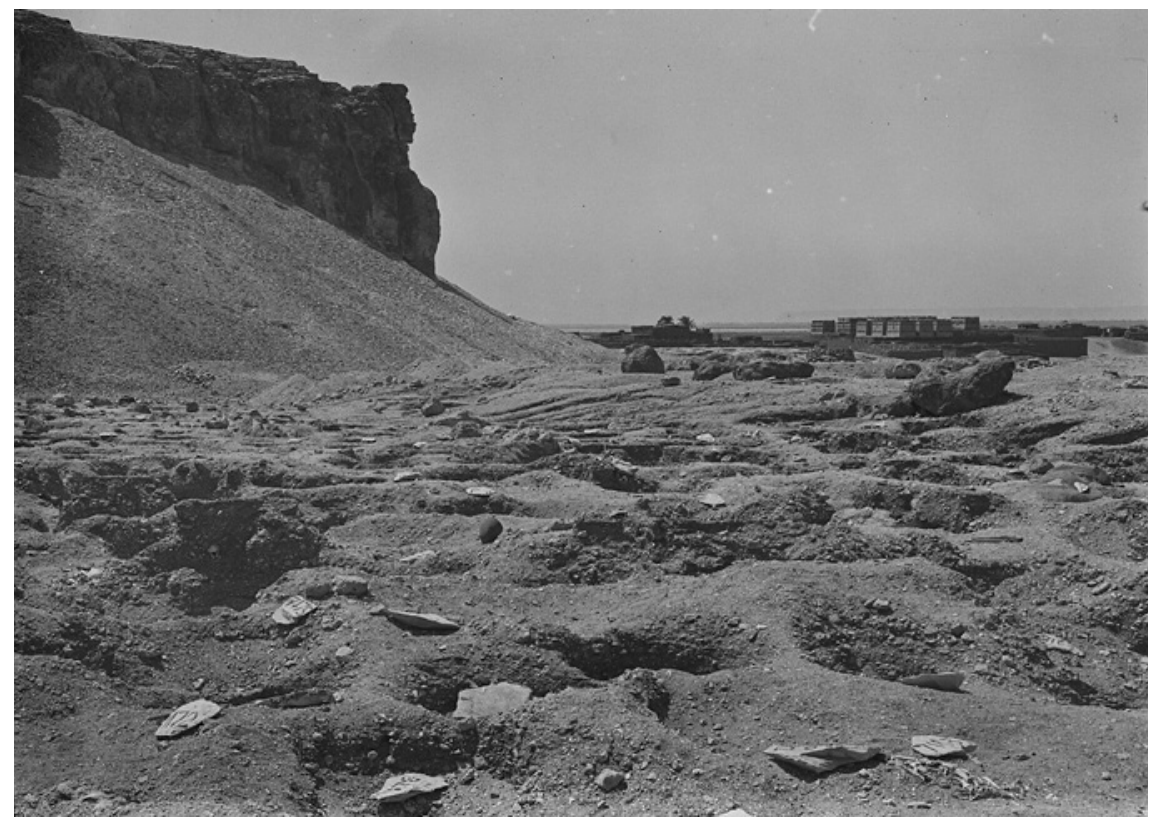

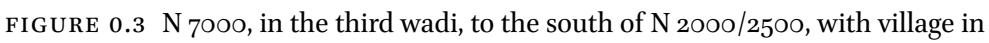
background. Note the numbered ostraca on the ground that denote the tombs. (NED-C-6745)

involved tracking skeletons' physical features, such as the shape of the head and face, to chart "racial characteristics." Scientists and Egyptologists no longer subscribe to racist theories of human development that resemble Smith's.

Most of the photographic plates taken by expedition members are today housed in the collection of the Museum of Fine Arts, Boston, although some of the images have been damaged. In the collection of The Phoebe A. Hearst Museum of Anthropology are $35 \mathrm{~mm}$ negatives made from fine-grain positives, which were made from the glass plate negatives in the Museum of Fine Arts, Boston. A still-ongoing project based at the Hearst Museum involves the herculean efforts of Joan Knudsen, Nancy Corbin, and Bob Bussey, who are cataloguing the original images and painstakingly identifying the objects and locations captured in the images based on Mace's notes and their own observations and knowledge of the collection. Note that in the staged shots of artifacts, some of the objects that are identified by tomb number may not have object numbers in the Hearst Museum or the Museum of Fine Arts, Boston, because not all of the artifacts found during the excavation were shipped to America. Where possible, thanks to the work of Joan, Nancy, and Bob, I have supplied an object number. In some cases, the object is only identified by tomb number. 


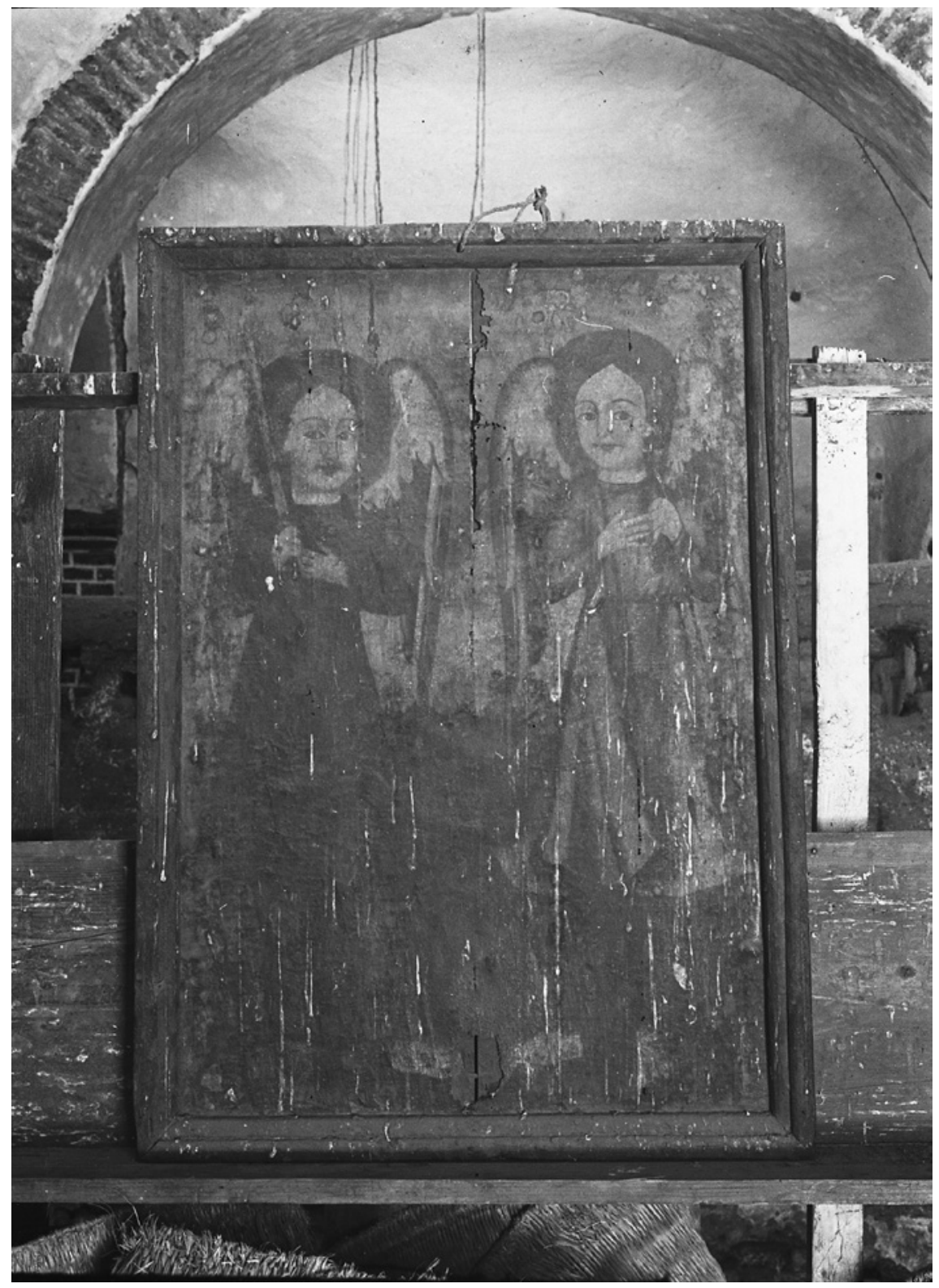

FIGURE 0.4 Icons in the Coptic church (NED-C-8219) 
Besides the photographs taken by the original expedition, a number of primary documentary sources were used in this publication, including Mace's draft of a manuscript, the tomb cards, and a map of the cemetery that someone (presumably Mace) made. The tomb cards contain the original notes and drawings made in the field. Thanks to confirmation from Peter Der Manuelian, at least two sets of handwriting, Reisner's and Mace's, have been identified on the tomb cards. Albert Lythgoe's may be represented there as well. For that reason, I have not attributed sole authorship of the tomb cards to Mace. The draft manuscript is Mace's preliminary preparation of some of the Coptic material for publication (Figs. 0.4-0.5). The original copies of the manuscript and the tomb cards are in the Museum of Fine Arts, Boston, and copies of them are in the collection of The Phoebe A. Hearst Museum of Anthropology. An unknown person or persons transcribed Mace's manuscript and some of the tomb cards. A copy of the former transcription is in the MFA and the Hearst Museum, while the latter is only at the MFA. New transcriptions were made for this publication, although those copies were consulted when questions arose due to faded pencil and scrawled handwriting. Thanks to the efforts of volunteers, such as Preston Staley, and student employees, such as Jocelyn Simlick and Andrea Miloslavic, those records have been digitized. Another digital resource was created by Alexandra Perkins and Lindsay Howard. Their digital map georeferences every tomb in this publication. To protect the integrity of the site, the map can be viewed only with login credentials in the University of California system. In the Museum of Fine Arts, Boston, there are camera-ready drawings of some of the Coptic garments, weaving techniques, and jewelry, as well as the Coptic inscription on the church. A handwritten note suggests that the artist might be L. F. Hall. Regarding the Coptic inscriptions found on ceramics in N 2016 and N 2431, there are sketches of the inscriptions on onion skin, Mace's transcription and English translations, and correspondence from Hubert Thompson to Mace regarding photographs that Mace had sent to him. Two photographs of Coptic inscriptions could not be located. The photograph 8469 that Mace references is not of Coptic inscriptions but of jewelry. The photograph 8578 must have been lost or destroyed, because it is not part of the site's photographic corpus.

Caroline Peck assembled another resource that is valuable for understanding the documentation of the work done in $\mathrm{N} 2000$ and N 250o. For her Ph.D. dissertation at Brown University, Peck (1958) worked on First Intermediate Period Naga ed-Deir material. Later, as a Teaching Associate in Brown's Egyptology department and then as an independent researcher housed in Brown's classics department, she waded through the original excavation materials of Reisner's 


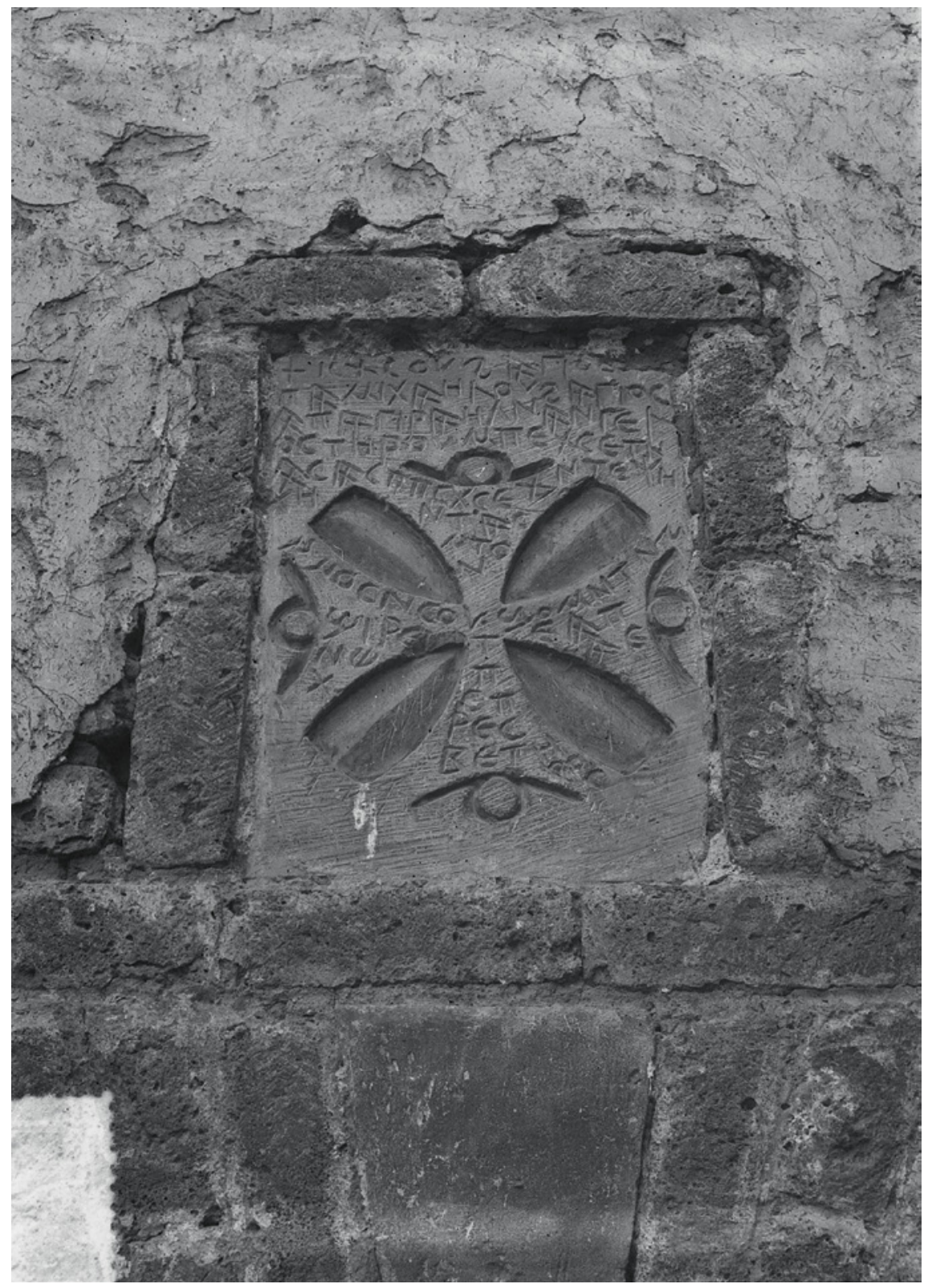

FIGURE 0.5 Inscription over the door of the Coptic monastery (NED-C-4750) 
team from Naga ed-Deir. The fruit of her work is now housed in the MFA. Binders of looseleaf pages contain her meticulous notes that organize and correlate the finds with the photographs from the original excavation.

One major difference between Mace's planned publication of cemeteries $\mathrm{N} 2000$ and $\mathrm{N} 2500$ and this publication of the same material concerns the images. The original documentation contains many photographs of human remains. Some of those images are of the body in situ in the tomb. Other burials were selected to be photographed in stages, as the layers of wrappings and clothing were removed from the body. None of the photographs showing human remains are used in this publication.

Mrs. Phoebe A. Hearst wanted to endow an anthropological museum on the West Coast of the U.S. with a collection as extensive as the museum that the University of Pennsylvania provided for residents of the Philadelphia area. Among those whom she commissioned to retrieve artifacts for the museum was a young archaeologist, a Harvard graduate and one-time American football coach, in 1889, at Purdue University.

Under the patronage of Mrs. Hearst, Reisner excavated a number of sites in Egypt, beginning in 1899, including at Qift, Deir el-Ballas, and el-Ahaiwah. Reisner's decision to work also at Naga ed-Deir was prompted by James Quibell's report that there had been looting at the site. Reisner applied to work there, was granted a concession in October 1900, and began excavating there in February 1901 (Figs. o.6-0.7). That first year, preliminary excavations were done in Cemeteries $\mathrm{N} 2000$ "on the north side of the second ravine" and N 2500 "on the north slope of the second ravine" (Reisner 1908, 4).

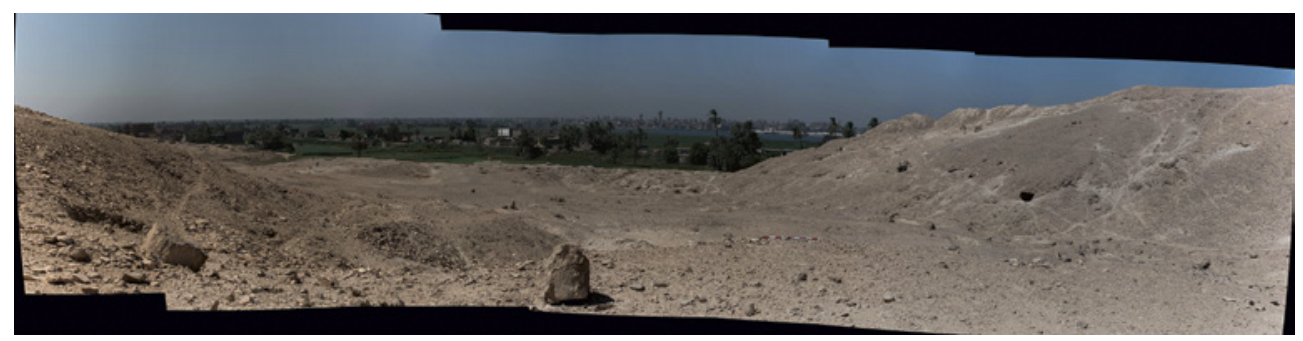

FIGURE 0.6 Panoramic view of second wadi looking toward cultivation PHOTO BY AYMAN DAMARANY 


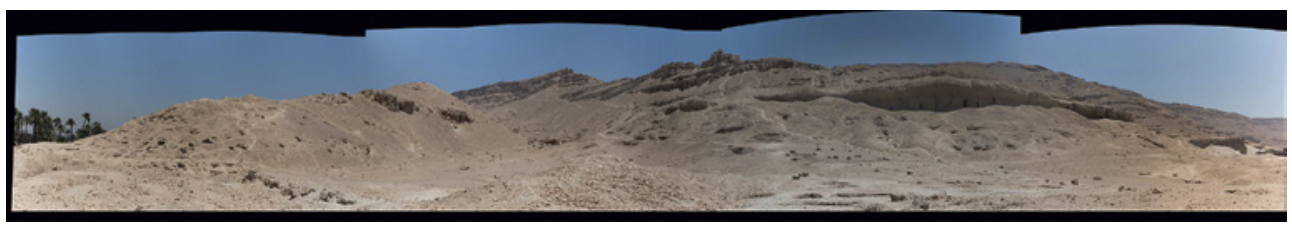

FIGURE 0.7 Panoramic view of second wadi from cultivation

PHOTO BY AYMAN DAMARANY

The departure of Frederick W. Green left a vacancy on the team. In the winter of 1901, Reisner hired Arthur C. Mace who began working with the expedition in 1902. Green's work the previous year in Cemetery N 2500 determined that there were a range of time frames, "early and late," represented in the burials there (George A. Reisner, "Introduction," in: Mace 1909, v). Coptic reuse of older burial grounds was discovered when the team was working Cemetery $\mathrm{N} 1500$ and realized that the Coptic burials there were in fill, not in earth. So they excavated deeper and found tombs with superstructures dating to earlier periods of Egyptian history (Reisner 1908, 4). During the 1903 and 1904 seasons, Reisner focused his efforts at Giza, while Lythgoe, who also published N 7000, and Mace, who also published N 350o, finished "mapping, planning, photography, etc." at Naga ed-Deir (Reisner 19o8, vii).

Reisner had great faith in the Egyptian staff that he employed at the site. In his introduction to the second volume of the Naga ed-Deir series, Reisner glowingly refers to the Egyptian members of his team as "the best trained and most effective gang in Egypt" (Reisner 19o8, vi; more on the term "gang" below). He made special mention of Said Ahmed Said, who headed up the photographic staff, took photographs, developed negatives, and made prints. To that team, we undoubtedly owe a great debt of gratitude for the images in this volume.

The importance of scientific method to Reisner's archaeology, a relatively new development in Egyptian archaeology at that time, is evident in his introductions to the Naga ed-Deir volumes. He enumerates five general points that drove his excavation work: an organized staff trained in careful excavation and recording; excavation of a complete site, not just individual tombs; the removal and recording layers of deposition in their reverse chronological order; drawings, notes, and photographs of all stages of work; and publication of the complete record tomb by tomb (Reisner 19o8, vii-viii).

Reisner's emphasis on the scientific work of archaeology is further emphasized in his statement, which accompanies point number 2, "The discovery of beautiful objects is, of course, greatly to be desired; but the search for Museum specimens is an offence against historical and archaeological research which 
is utterly unworthy of any institution which pretends to be devoted to the advancement of knowledge" (Reisner 1908, viii).

Reisner's scientific method of excavating a field was somewhat thwarted due to the uneven distribution of burials. His field techniques in 1901 were to assemble the workers into eleven groups, each headed by one man-Ibrahim Omar, Sa'eed Mahfûz, Mustapha Aisa, Mahmud Khalleel, Hasan Hasib-enNebi, Berberi Ahmed, Mohammed Aleo, Ahmed el-Mizlif, Salman Salim, Abu-'l-Hasan Osman, and Amr Alean (Reisner 1932, 2-3). Each of the eleven groups was assigned one set of numbers ten digits apart (591, 581, 571, etc.) and set to work along the cemetery edge. As the groups' work progressed into the cemetery, they assigned each burial a number in their particular number sets, although some groups found more burials in their sections of land than did others (Reisner 1932, 3-4).

While working for Mrs. Hearst, Reisner's expedition became organized under F. W. Putnam of Harvard who was instrumental in setting up the anthropology department at the University of California, Berkeley. In 1905, Reisner's excavation work found a new home at Harvard University and the Museum of Fine Arts, Boston. For this reason, the artifacts from his excavations at Naga ed-Deir cemeteries $\mathrm{N} 2000$ and $\mathrm{N} 2500$ are now housed in the collections of the Phoebe A. Hearst Museum of Anthropology at the University of California, Berkeley, and the Museum of Fine Arts, Boston.

The zone that Reisner and his team excavated at Naga ed-Deir lies north of the modern village of Naga ed-Deir and south of the tomb of Sheikh Farag. Between these two areas are limestone cliffs that abut the cultivated plain. Three deep wadis cut into the cliffs in an east-west direction, running from the plain into the towering folds of the rock. Rock-cut tombs are found in the cliff faces, and shaft graves and the remains of mastabas are located in soil accumulations at the bases of the wadis (Figs. o.8-0.9).

Reisner divided the excavation area of Naga ed-Deir into different cemeteries, ranging in number from $\mathrm{N} 100$ to $\mathrm{N}$ 10ooo. Over time, he changed his own labeling system so that some cemeteries that he refers to in notebooks (e.g., $\mathrm{N} 4000$ ) or in the initial publication (e.g., $\mathrm{N}$ 10000) are never again mentioned. The original Naga ed-Deir volumes treat cemeteries $\mathrm{N} 500-\mathrm{N} 900, \mathrm{~N}_{1500}$, N 3000, N 3500, and N 7000 (N 500-N 900: Reisner 1932; N 1500/N 3000: Reisner 1908; N 3500: Mace 1909; N 70oo: Lythgoe 1965; Friedman 1981). The 


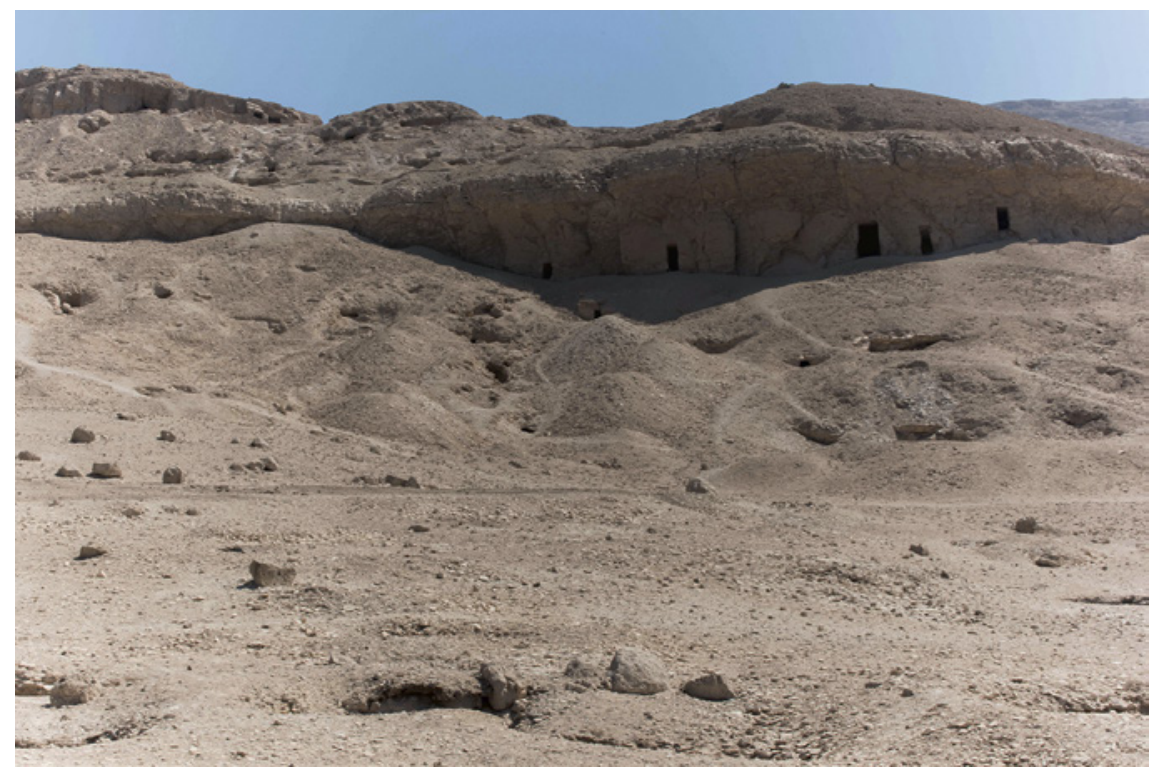

FIGURE 0.8 Rock-cut tombs on southern slope of wadi and pit burials below PHOTO BY AYMAN DAMARANY

unpublished cemeteries are $\mathrm{N} 100$ (also referred to as $\mathrm{N} 100-\mathrm{N} 400$ ), $\mathrm{N}$ 9000, near Sheikh Farag, and N 2000 and N 2500, which this project will publish. Cemeteries $\mathrm{N}_{2000}$ and $\mathrm{N}_{25} 50$ are located near the mouth of the second of the three wadis (Fig. o.10). (For a complete bibliography on the site and its artifacts, see the Foreword to this volume.)

In the first volume of the Naga ed-Deir series, Reisner described Cemetery $\mathrm{N} 2000$ in this way, "This cemetery of the sixth to eighth dynasties extends up the sides of the second ravine and over the low alluvial mound on the north side of the mouth of the ravine. The top of the alluvial mound contains pit tombs of the sixth and seventh dynasties and, mixed with these, a great number of narrow Coptic graves. The side of the mound along the ravine is lined with chambered tombs of the tenth to eleventh dynasties, cut in the hard gravel" (Reisner 1908, 1; Figs. o.11-0.13). In his draft manuscript published here, Mace places $\mathrm{N} 2000$ "on a bluff just north of the second ravine. It is bounded on the west by the road along the edge of the cultivation, on the south and southeast by the old watercourse, while to the north it merges gradually into the steep slopes of Cemetery 3500" (pages 492-493).

Reisner described the gradual erasure of the superstructures of the $\mathrm{N}_{500}$ tombs due to four major factors: weathering by wind and rain, later Coptic 


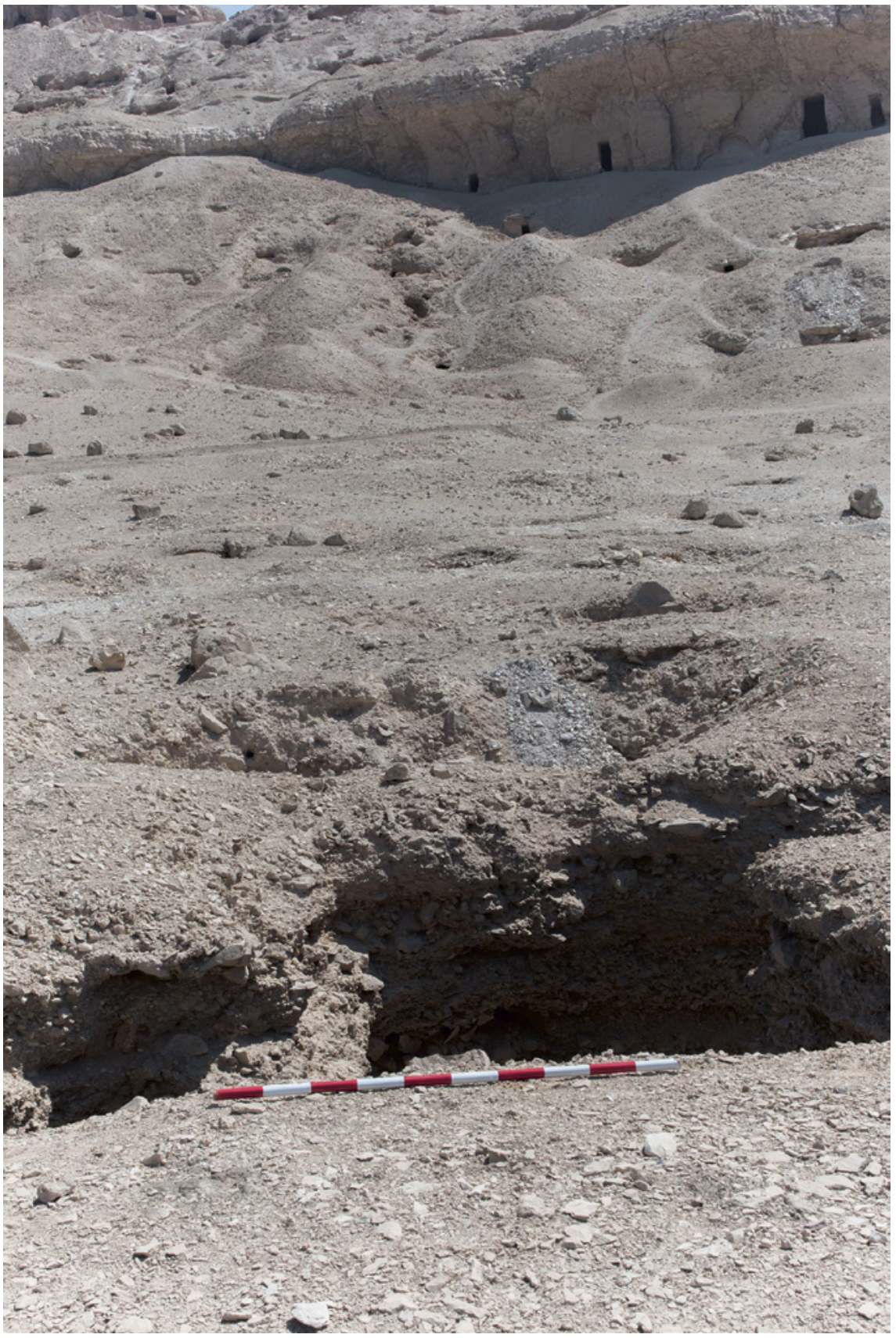

FIGURE 0.9 Pit burial below rock-cut tombs

PHOTO BY AYMAN DAMARANY 


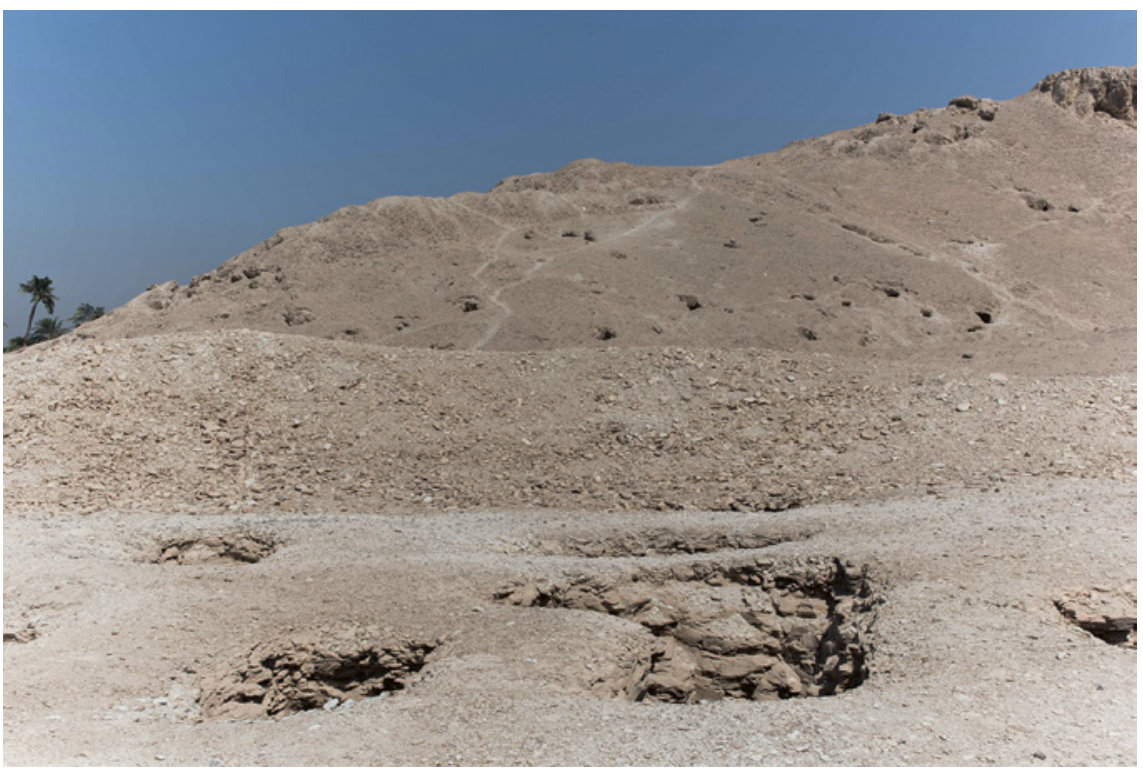

FIGURE 0.10 Southern side of northern slope of wadi with pit burials in foreground and hillside burials in background PHOTO BY AYMAN DAMARANY

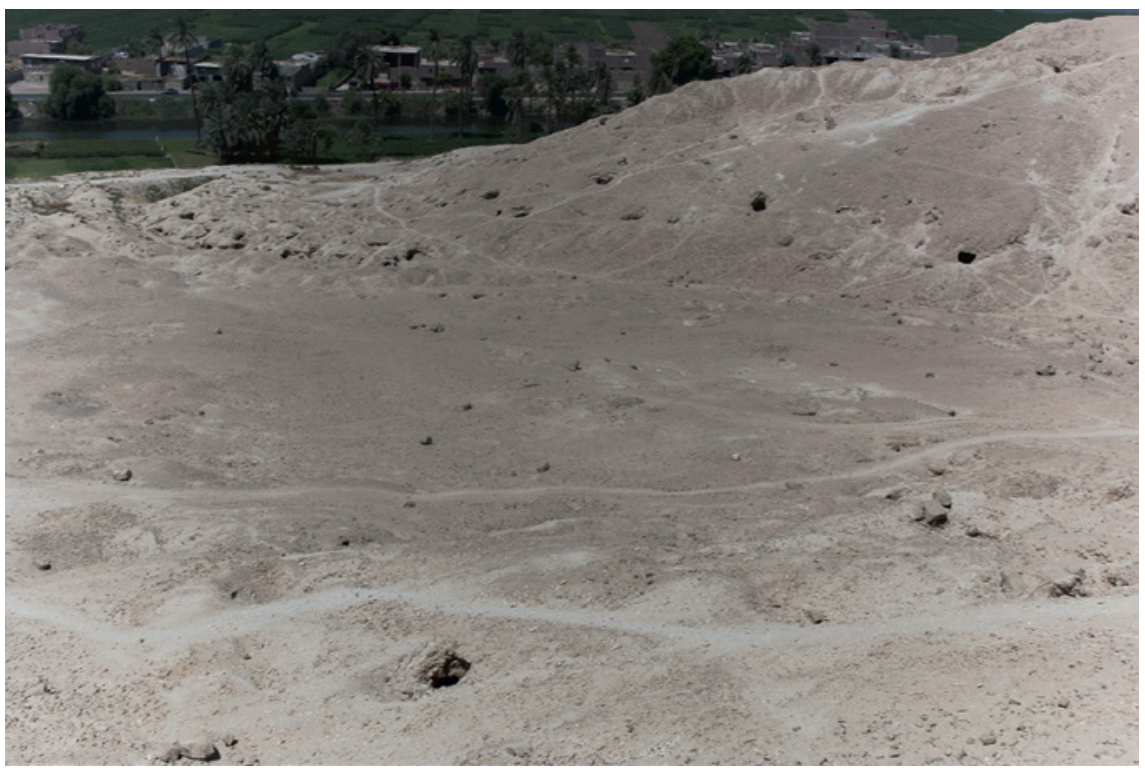

FIGURE 0.11 Southern side of northern slope of wadi with cultivation in background PHOTO BY AYMAN DAMARANY 


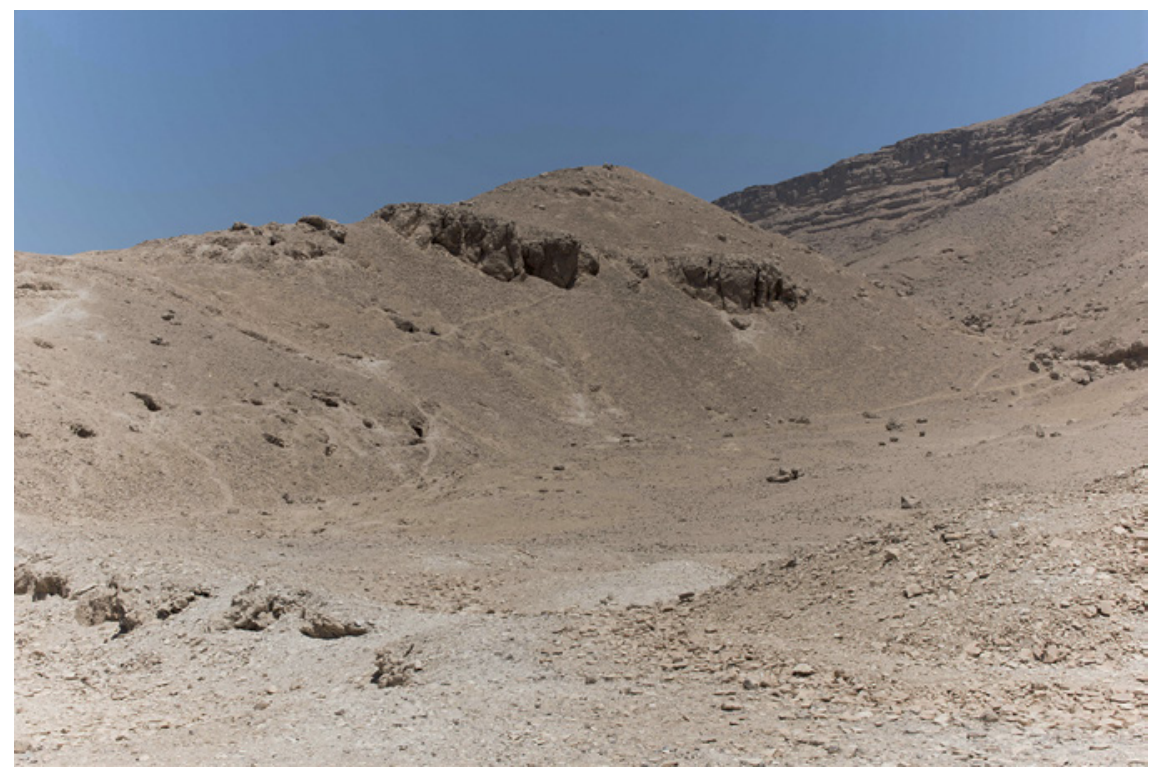

FIGURE 0.12 View from cultivation into the second wadi with hillside burials on left PHOTO BY AYMAN DAMARANY

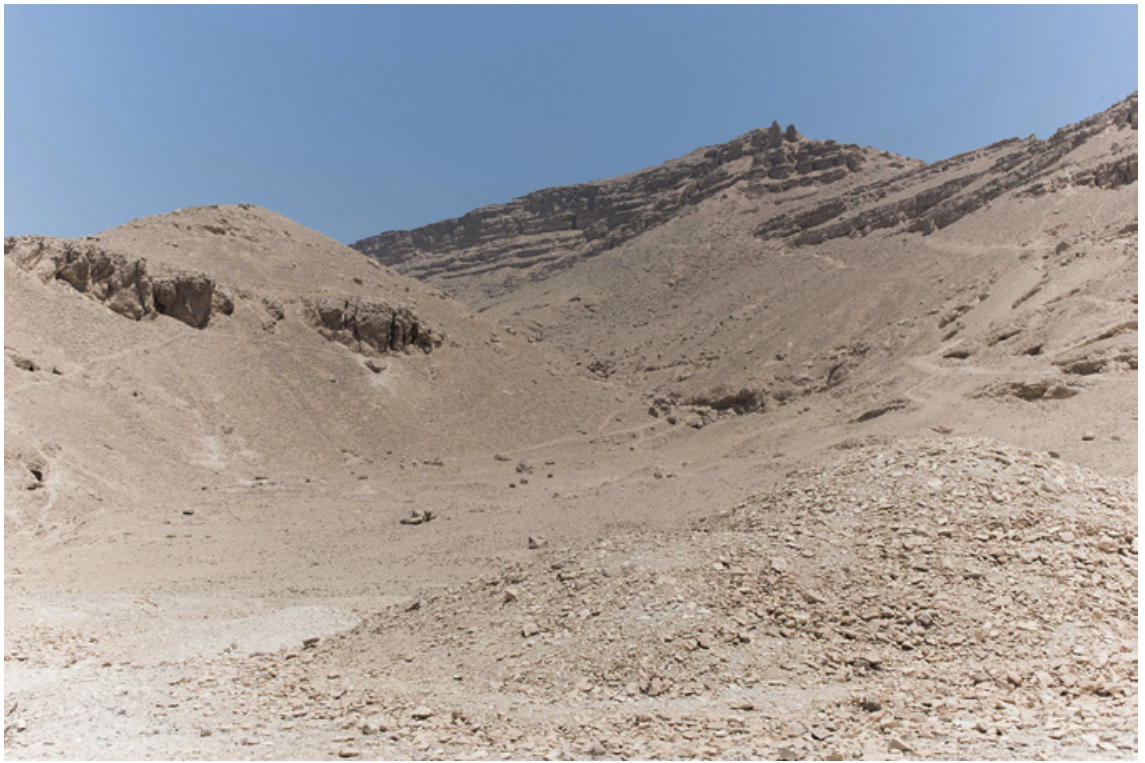

FIGURE 0.13 View from cultivation into the second wadi PHOTO BY AYMAN DAMARANY 


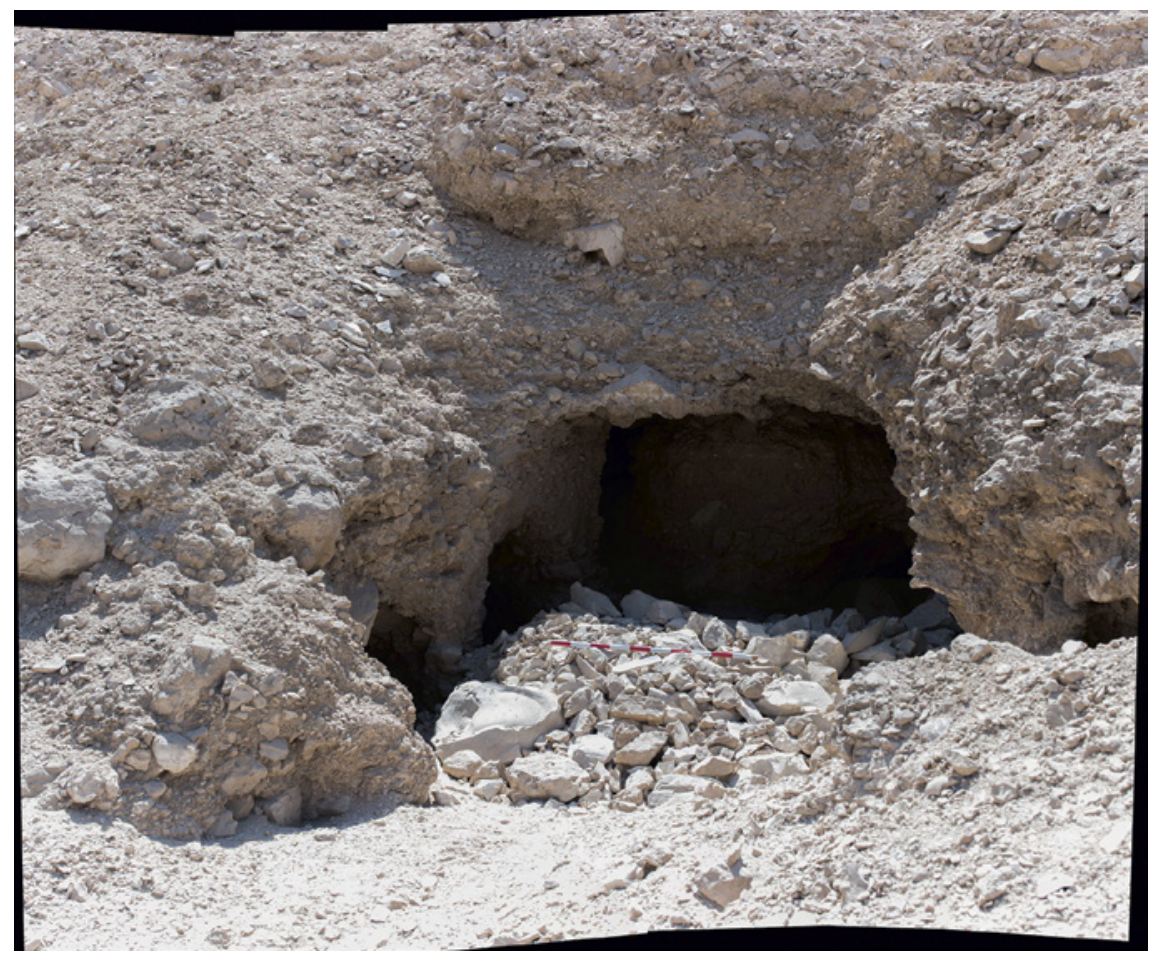

FIGURE 0.14 Entrance to a tomb

PHOTO BY AYMAN DAMARANY

burials intruding on earlier burials, excavation of mud brick and mud debris by modern diggers looking for the raw materials to make new bricks, and plundering of burials (Reisner 1932, 3). All of those factors also contributed to the damage done to the tombs and burials in Cemeteries N 2000 and N 2500 (Fig. o.14).

Cemeteries N 2000-N 250o contain burials of the First Intermediate Period/ Middle Kingdom (potentially the late Old Kingdom as well) and the Coptic Period, although there are many Coptic burials at Naga ed-Deir outside of the 2000 number range. Two of those $\left(\mathrm{N}_{3747}, \mathrm{~N} 4511\right)$ are included in this publication for one reason only: both of those tombs are discussed, and factor quite prominently, in Mace's draft of his publication. An anonymous document at the MFA in Boston named "Appendix I List of Coptic Tombs from Naga edDeir" also lists the following tomb numbers: $30,73,74,81,83,89,90,100,105$, 181, 453b, 50o, 520, 563, 587, 641, 771, 781, 1535, 1581, 1584, 1596, 16o1, 1629, 3526, $3529,3586,3718,3723,3925,4203,4318,4354,4356,4512$. They are not included in this publication because they are outside of its scope. 
On the N 2640 tomb card, Mace's note indicates that "in the notebook" $\mathrm{N} 2640=\mathrm{N}_{3747}$, thus, associating those two tomb numbers with one another. On the map, $\mathrm{N} 3747$ is located directly next to $\mathrm{N} 2640$ and is surrounded by a number of tombs in the $\mathrm{N} 2000-\mathrm{N} 2500$ range that cluster around it. At more of a distance, to the north and northwest of $\mathrm{N} 3747$ (so farther up the slope from the $\mathrm{N} 2000-\mathrm{N} 2500$ tombs), are tombs in a higher number range: $\mathrm{N} 3746,3579$, and others.

$\mathrm{N} 3747$ is not unusual in having a number that does not correspond to its cemetery number. In the Naga ed-Deir cemeteries, tomb numbers did not necessarily indicate a location in a particular cemetery. In the first Naga edDeir volume, Reisner discussed N 3041, a communal grave dating to the Coptic era that enlarged and reused a Middle Kingdom grave. The Coptic burial, he wrote, belongs "undoubtedly to cemetery 2000 situated on the opposite bank of the ravine" because "cemetery 3000 contained no other Coptic burials" (Reisner 1908, 67, pl. 69d).

The situation concerning $\mathrm{N} 4511$ is more complex. No case can be made for $\mathrm{N} 4511$ being a part of Cemeteries $\mathrm{N} 2000$ or N 2500 based on geography. The location of $\mathrm{N} 4511$ is so far removed from the tombs in this publication that it is not even on Mace's map of the cemetery (Map 2). N 4511 can be found on a very large map in the collections of the Hearst Museum and the MFA labeled "Naga-êd-Dêr." Four separate maps of the site were joined to make one large map. The rightmost map has a north arrow labeled October 1902. On that map, tomb 4511 is found in the block $\mathrm{F}$ (horizontal), $\mathrm{d}$ (vertical). Mace singled out that tomb for inclusion in his publication because of one critical find that was in the tomb: a coin that he dates to the third or fourth year of Justinian (529-53O CE). (Mace provides two different dates in his publication, $529 \mathrm{CE}$ and $530 \mathrm{CE}$.)

That coin was the only certain dating criterion that Mace had in all of the burials. His decision to include it in his publication reflects the importance that he attributed to it as a dating element and the concomitant uncertainty he must have felt regarding any other possible dating that might emerge from the material. Because the coin was used as a pendant ("pierced and hung round a child's neck"), it must not have had value as a coin, per se. Mace guesses that the coin would have been kept and used in this way for a period of time not more than 50 years after its date of manufacture. Thus, "with some confidence," Mace points to the second half of the sixth century CE as the date of "our cemetery" (by which it is unclear if he means N 2000-N 2500, of which $\mathrm{N} 4511$ is not a part, or if he dates all of the Coptic burials at Naga ed-Deir to that time frame). 
Mace intended his publication to be a scientific record of only the Coptic burials in Cemeteries $\mathrm{N} 2000$ and $\mathrm{N}_{2500}$. Some of the objects in the First Intermediate Period/Middle Kingdom tombs from those cemeteries were published by Reisner in Part III of his Naga ed-Deir series (Reisner 1932). An example of a difference between Reisner's publication and this one is seen in Reisner's drawing (Reisner 1932, fig. 50:13) of a scarab from N 2071b (now with the object number PAнмA 6-14374) and the drawing and image in this volume (Figs. 4.1-4.2). Furthermore, although Reisner did mention some artifacts from these burials in the third volume of his Naga ed-Deir series, he did not publish a complete record of the First Intermediate Period/Middle Kingdom burials, as this volume does.

Almost all of the tomb cards are written in Mace's handwriting. In the few instances where his pencil marks have faded to such an extent that his words are now illegible, I noted this in the text with either [ed.:?] or [illegible]. Some of the tomb records ( $\mathrm{N} 2001,2021,2041,2501,2511,2521,2542)$ were written in 1901 (Reisner 1932, 2, fig. 1, a-b). Reisner's notes on the contents of those tombs

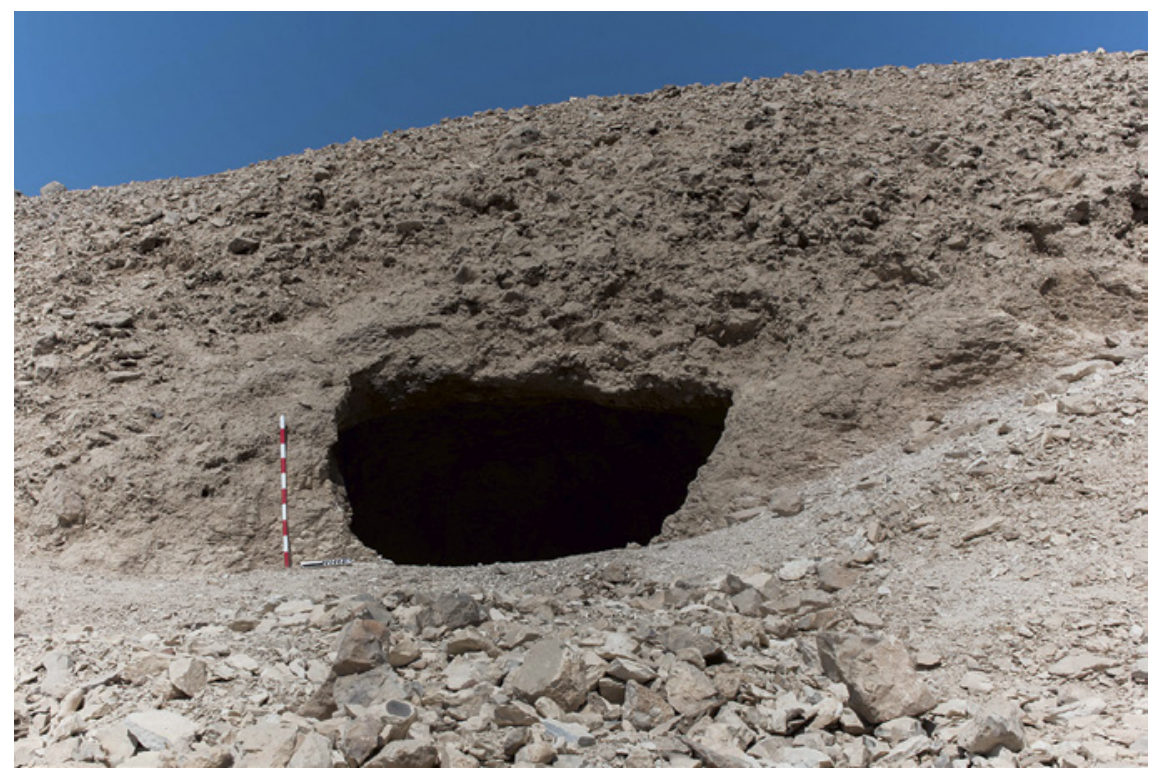

FIGURE $0.15 \quad \mathrm{~N} 2511$. This is the "hillside cave" that Reisner excavated as part of his preliminary work in 1901 . When the cemetery was systematically excavated a few years later, another burial was also given this number. 2511 on Reisner's map (1932, Fig. 1) is the hillside cave. N 2511 on Mace's map is the Coptic burial. PHOTO BY AYMAN DAMARANY 


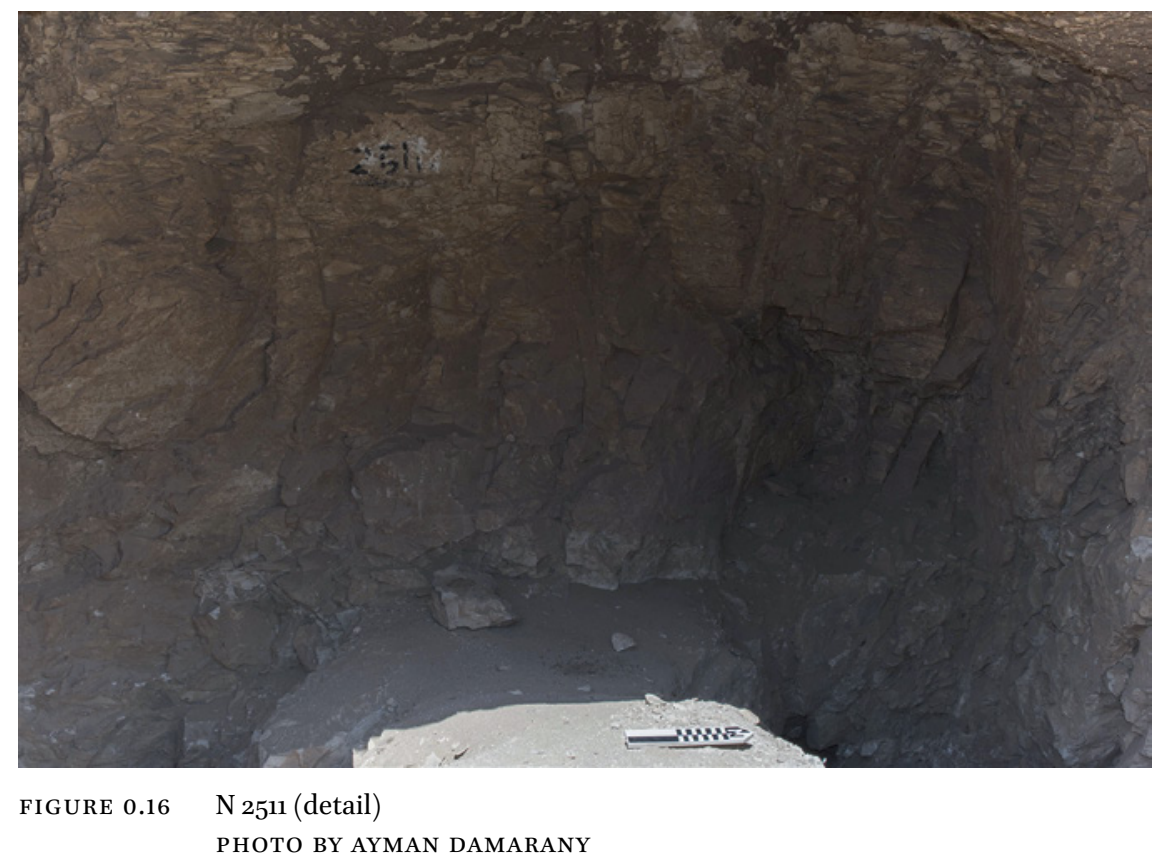

are much more abbreviated than Mace's. The tomb numbers themselves seem to have not been reserved because $\mathrm{N}$ 2001, 2041, 2501, and 2511 were reused when Mace directed the excavations of the cemeteries (Figs. 0.15-0.16). For example, one card lists tombs $\mathrm{N} 2001, \mathrm{~N} 2021$, and $\mathrm{N} 2041$. The short notations concerning N 2001 ("Rotten wooden box empty.") and N 2041 ("Empty pits. Rectangular cloth. Shells, etc.") indicate that they cannot refer to the same $\mathrm{N} 2001$ and N 2041 later excavated by Mace. According to Mace's numbering system, N 2001 contained an intact Coptic-era burial, and N 2041 contained nothing ("Absolutely plundered out."). For the sake of completeness, Reisner's brief descriptions have been included in the Catalogue of Tombs.

The Catalogue of Tombs lists all of the burials in Cemeteries N 2000 and N 2500. The list is compiled from two sources: Mace's manuscript draft and the tomb cards. Mace did not intend to include in his publication all of the tombs that are published here. From his draft manuscript, it is clear that Mace intended to publish only the two cemeteries' Coptic burials, not any earlier burials, and only those Coptic burials that had a certain level of detail. For example, tombs N 2614 
and $\mathrm{N}_{2648}$, which admittedly do not provide much information, were recorded on tomb cards, but were not included in Mace's draft of the tomb catalogue.

Because this project is as much interested in the ways that work was donethe organization of work in the field, the methods of documentation, and the excavators' approach to the material-as well as the results of the workobjects found and burials unearthed-all of the information recorded on tomb cards has been included here. The Coptic tombs, the First Intermediate Period/Middle Kingdom tombs, and the tombs of uncertain date that were found completely empty or destroyed are all documented in the Catalogue (Figs. 0.17-0.18). The descriptions and drawings, even of the tombs that yielded no finds, are historical documents in their own right.

Two photographs provide insight into work and life in the field. A photo taken looking over $\mathrm{N} 2000$ in the north, to $\mathrm{N}_{3000}$ and $\mathrm{N} 1500$ in the south, shows us the excavation camp located on the slope of $\mathrm{N} 3000$ (Fig. o.2). An image taken from $\mathrm{N} 7000$, located to the south of $\mathrm{N} \mathrm{2000/N} \mathrm{2500,} \mathrm{shows} \mathrm{the}$ village of Naga ed-Deir in the background (Fig. O.3). It is included in this publication because it is a historical record of the living village and because the photo reveals Reisner's method of numbering tombs on ostraca on the ground.

The tomb data in the tomb cards is complete, but Mace's manuscript draft, which treated only the Coptic tombs, unfortunately jumps from page 3 to page 14. So the information that he recorded there for Coptic tombs $\mathrm{N} 2005$ through N 2170 is now lost. Those pages may have existed as recently as the 1970s, as evidenced by a document in the MFA entitled "Appendix II Catalogue of the Burials." The author of that document, which is dated March 29, 2012, claims to have compiled the information from Mace's 33-page manuscript and the tomb cards "as transcribed by an anonymous author in the 1970s." If Mace's manuscript was indeed 33 pages long in the 1970s when the anonymous author transcribed the material, then the now-missing pages still existed at that time.

Although the missing pages of Mace's manuscript may have been a source for the material that now comprises Appendix II, the data in the Catalogue for tombs $\mathrm{N} 2005$ through $\mathrm{N} 2170$ was compiled exclusively from the tomb cards. The reason for this is that the data on the tomb cards is much more detailed than what is found in the Appendix, which has shorter descriptions and no illustrations, and because the discrepancies between the Appendix and the tomb cards cannot be resolved by checking Mace's original work, which is no longer accessible.

When tombs were documented on both tomb cards and in the draft manuscript, I combined the information in both sources to form a more complete record in the tomb catalogue. The reason for this is that I noticed that certain interesting and instructive details had been omitted from Mace's draft 


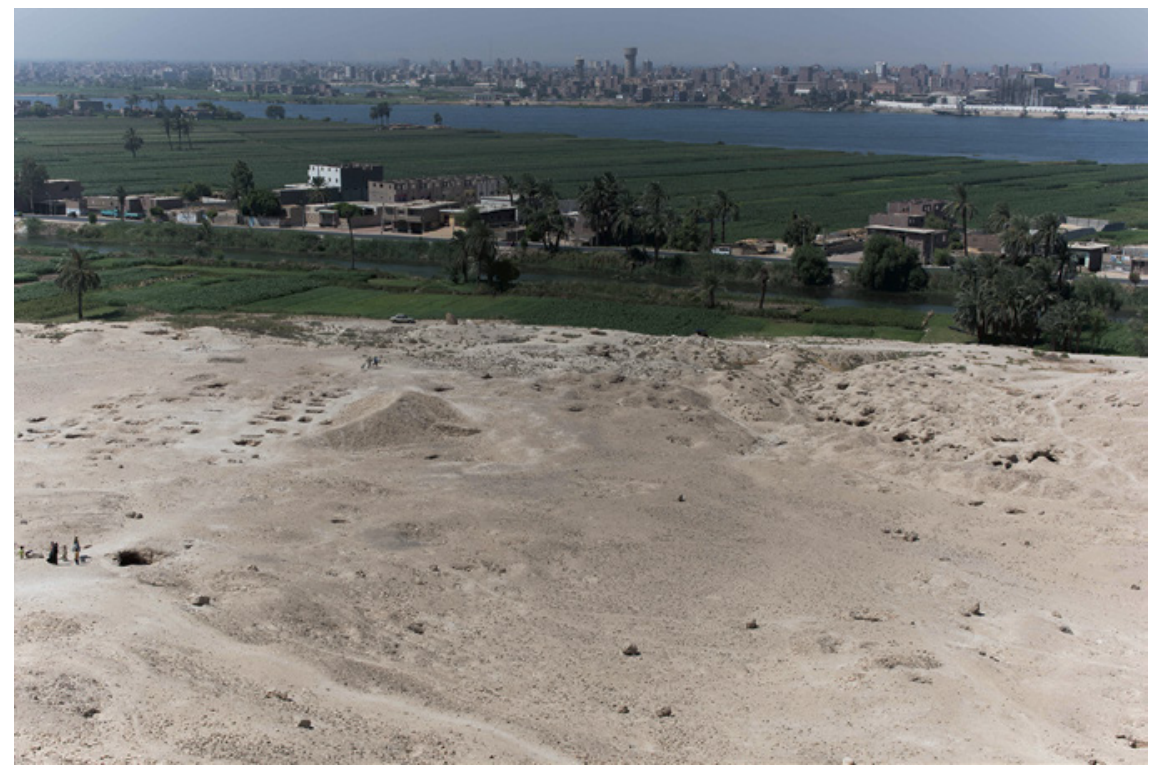

FIGURE 0.17 On right, southern side of northern slope of second wadi ( $\mathrm{N} 2000)$. On left, a series of pit tombs.

PHOTO BY AYMAN DAMARANY

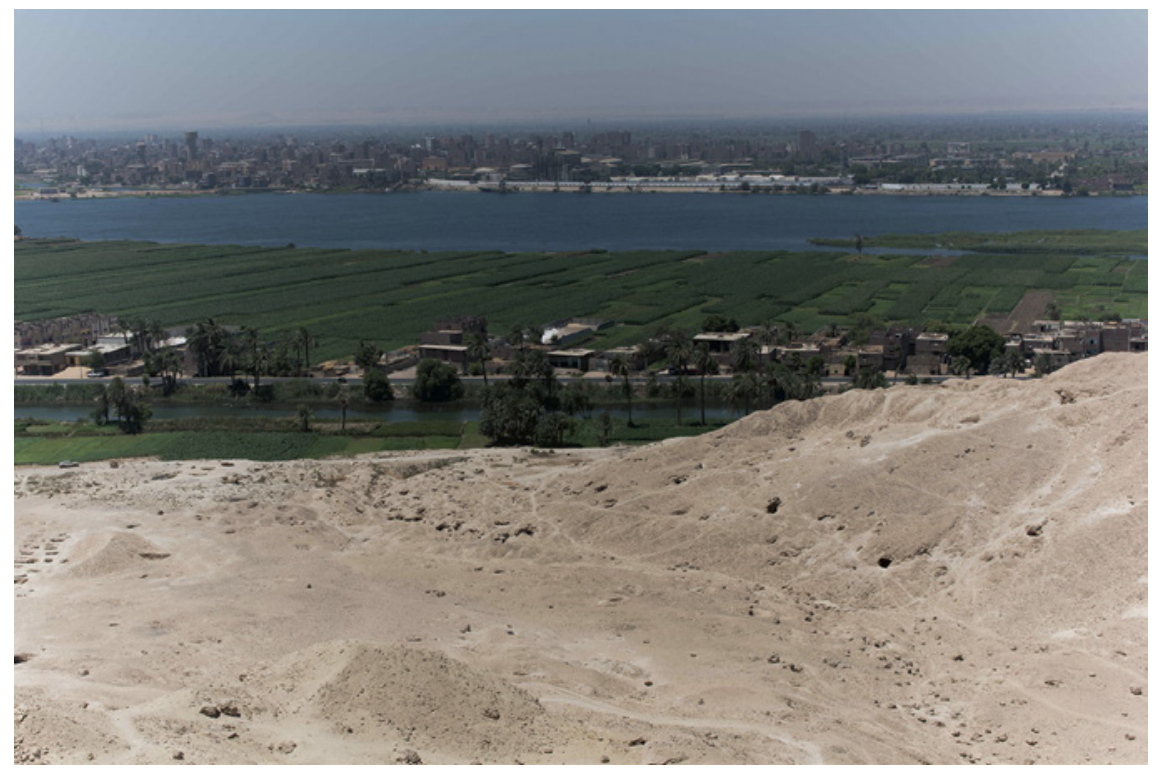

FIGURE 0.18 Same view higher up the slope, with city of Girga in background PHOTO BY AYMAN DAMARANY 
manuscript. For example, on the tomb cards, the level of detail about and drawings of the ornamentation on the Coptic garments is quite extensive. There is no indication that Mace planned to include those drawings in his publication. In fact, he notes plans to produce in the future a "supplementary volume" to address "the question of design" and to present the garments in color.

In a few instances, the information provided on the tomb card was altered by Mace for his manuscript. For example, in $\mathrm{N} 2004$, the bracelets are described as bronze on the tomb cards and copper in the manuscript. In those cases, I included the later (i.e., manuscript) information, rather than the earlier (i.e., tomb card) information.

Mace's choice of word was preserved whenever possible. Changes were made where necessitated by grammar (such as when "that" was substituted for "which"), the standards of American English (such as when "pit" (of a drupe) was substituted for "stone" and "motifs" for "motives"), and modern conventions (such as when "aged" was substituted for "aetat" and "approx." for "circ."). Other substantive changes were avoided. Thus, although today, we might more commonly refer to a particular Coptic garment as a "tunic," I did not alter Mace's description of the garment as a "shirt." To aid in understanding Mace's sometimes brief notes, punctuation, especially commas, and editorial notes, enclosed in brackets, were inserted into the text when necessary.

Mace frequently left a blank or inserted a question mark in the narrative on the tomb cards when he was unsure of a detail. For example, if an object in the tomb was unidentifiable to him ( $\mathrm{N}$ 2005), if he was dealing with unknown substance ( $\mathrm{N}_{2631}$ ), or if he was unsure of the measurement of a garment ( $\mathrm{N} 2009$ ), he would simply insert a question mark, apparently intending to resolve the issue at a later date. Those question marks have been left in the narrative with editorial notes added as necessary.

Mace's drawings of pits and burials on the tomb cards were often comprised of rough and somewhat crooked lines. He was, after all, drawing in freehand, in pencil, in the field. Comparing his drawings to the published drawings of burials in the earlier Naga ed-Deir volumes that he and Reisner wrote, it was clear that they had made certain editorial decisions regarding their drawings, such as straightening wobbly lines made by an unsteady hand. So when rendering Mace's drawings from cemeteries N 2000 and N 2500 in digital form, we also straightened wobbly lines.

Many of the tombs include a depth measurement. Those measurements were probably based on an arbitrary datum line, as was the practice when excavating Cemeteries N 500-90o (Reisner 1932, 180).

An interesting fact emerged from comparing the records of the Coptic burials on the tomb cards with the records of those same burials as Mace compiled them in his manuscript. On the tombs cards, the layers of clothing and linen 
that enveloped around bodies are described from the outside in, apparently recording each layer as the body was unwrapped, including extra paddings and items, such as palm sticks and salt, that were sprinkled over the body. In the draft of his manuscript, Mace reverses the order and describes the wrapping and other items from the inside out, as if he is reburying the person. For this reason, the garments on the bodies in tombs $\mathrm{N} 2005^{-\mathrm{N}} 2170$ will be described in the reverse order as the rest of the burials.

Mace conceptualized the earlier and later burials of these two cemeteries as quite distinct from one another. On the tomb cards, the later burials are often, although not always, identified as "Copt." But then in two key instances, Mace betrays his sense of a cultural break between the First Intermediate Period/ Middle Kingdom and the Coptic era. On the tomb card, he notes that N 2296 is the "Upper part of an Egyptian burial," a description that leaves one wondering what a non-Egyptian burial in the cemetery might be. The question is answered in the record for $\mathrm{N}$ 2514, a shallow grave of an uncertain time period that Mace describes as "Copt or possibly Egyptian." For Mace, the Coptic culture of Naga ed-Deir is distinct from its pharaonic Egyptian culture, a view that is not shared by the authors of this volume.

On the tomb cards, Mace wrote "S." or "See Smith" to denote Grafton Elliot Smith's work on bodies in the Coptic-era burials. In many cases, observations are recorded on the tomb card, seemingly added by Mace at a later date, based on how the description of the person is often squeezed in between other notes. For example, the burial in N 2306 was studied by Smith, as noted by the "S." at the top of the tomb card. Mace's description begins "Copt." and "head S.W." Between those two notes is a large gap in which is written "female circ ${ }_{17}$ ?" This data is also recorded in Mace's hand, but in a slightly smaller script that floats above the line of the two flanking notes. In other cases, however, Smith's observations are not recorded on the tomb card. For example, the tomb card for N 2307 is labeled "See Smith," but contains no other data.

Mace had a certain abbreviated way of writing in his notes on the tomb cards. Many measurements lack a unit of measure. The tomb card for N 2243 notes that underneath the burial of a Coptic child was a second burial of a man "3o down," which is Mace's usual way of referring to depth. In his draft manuscript, Mace rephrased the note so that it reads, "The second burial was $30 \mathrm{~cm}$ below the other." Thus, from N 2243, we learn that Mace's unit of measuring the depth of the burials was centimeters.

The body's "usual position," a phrase that Mace often uses with regard to Coptic burials, is the body laying on the back, with the head to the west, and the arms by the side of the body. The "usual way" of wrapping the body in Coptic burials was with the sides of the shawl thrown over the body first and then the ends thrown over the body. Mace explains this in $\mathrm{N} 2636$. 
There are two crucial points that Mace did not remark on in his manuscript. Mace notes that "the [Coptic] bodies in this cemetery were not, in the strict sense of the word, mummified, though a certain amount of care was taken to preserve them" (page 496). But the Coptic burial N 2616 suggests that there was some attempt to preserve the body in a manner similar to mummification. The note on the tomb card observes, "Lower opening of the intestine was patent, and the intestine had been stuffed with preservative material." The second point of interest involves evidence of dentistry or some type of oral surgery. Regarding N 2818, also a Coptic burial, Mace records, "Very few teeth left. On left side of lower jaw, a large hole drilled right through."

In his notes, Mace uses a number of Arabic words and technical terms, some of which are defined in the earlier Naga ed-Deir volumes. On the tomb card for $\mathrm{N} 2300$, Mace records stacks of "sont" that were found under the body. In his manuscript, he changes this to "acacia," thus providing his own explanation of this word. Others are as follows:

$\begin{array}{llll}\text { gebel } & \text { geological stratum } & \text { radim } & \text { fill } \\ \text { tufl } & \text { geological clay } & \text { moghar } & \text { cave } \\ \text { balat } & \text { stone slab } & \text { kusha } & \text { temporary structure? } \\ \text { shaum } & \text { wooden staff } & \text { nabut } & \text { wooden staff } \\ \text { shugf } & \text { pottery sherd } & \text { gotn } & \text { cotton? } \\ \text { atl } & \text { tamarisk (Lane 20oo, 40) } & \text { sont } & \text { acacia } \\ \text { sesaban } & \text { sesban (Sesbania sesban, } & \text { i.e., Egyptian riverhemp, in the } \\ & \text { legume family) } & \end{array}$

Other abbreviations:

A alluvial M Marl

Although no key was included on this map (see Map 2), we can surmise the key from Mace's map in his first Naga ed-Deir publication (Mace 1909, pl. 58). His description in his draft manuscript, "the early tombs are marked in black, while those of the Coptic period are shown in red," confirms that he followed the model of his published map for the map of these cemeteries. The tombs inked in black are earlier ones, and the tombs inked in red are the later (Coptic) ones. Diagonal lines indicate brick construction, half moons indicate stone construction, Xs indicate the outline of rock-cut chambers, and dotted lines indicate underground burial chambers. 
Someone, presumably Mace, penciled in the tomb numbers on the map before inking them. Very often, the pencil marks are still clearly visible, which occasionally indicate minor errors. For example, $\mathrm{N} 2404$ is written in pencil on the map, but the tomb was inked as $\mathrm{N} 2405$. $\mathrm{N} 2846$ was written only in pencil, not in ink.

\section{Dating Burials}

Although Mace intended to publish only the Coptic burials in $\mathrm{N} 2000$ and $\mathrm{N} 2500$, there are a number of earlier burials that he refers to in his manuscript as dating to Dynasties 6 through 9, and once he mentions that the rock-cut tombs on the site date to Dynasties 5 through 11 . This corresponds generally with Reisner's earlier description of $\mathrm{N} 2000$ as containing burials, including pit tombs in the alluvial soil, from Dynasties 6 through 8 and from the Coptic era, along with chambered tombs from Dynasties 10 and 11 (Reisner 1908, 1).

Reisner and Mace's dating of this early set of tombs is confirmed by the

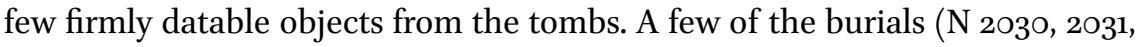
2032, 2093, 2100, 2507) can be positively dated due to the distinctive First Intermediate Period stelae that were found in them (Brovarski 2018). One alabaster vase (PAH MA 6-14424) inscribed with the royal name Meryre provides a terminus post quem for $\mathrm{N} 2096$ of Dynasty 6, after Pepy I adopted that throne name. A date to the late Old Kingdom or after is supported by the black veined vessel (PAHMA 6-14420) also found in the tomb. So although there may be a few burials that date to the late Old Kingdom, for example, possibly N 2096, the majority of the tombs seem to date to the First Intermediate Period/ Middle Kingdom.

Many of the tombs of indeterminate date are described on tomb cards as "probably a pit and chamber" (N 2012) or "may have been pit and chamber" ( $\mathrm{N}$ 2047). In those cases, Mace seems to be signaling that the tombs are datable to Dynasty 4 or later. This supposition rests on Reisner's original dating of shaft and chamber tombs at Naga ed-Deir to Dynasty 4 (Reisner 1908), although he amends that to Dynasty 5 in his later publication (Reisner 1932). This conclusion is confirmed by Mace's comment on the joint tomb card for $\mathrm{N} 2844$ and 2845, where he sets up a contrast between pit and chamber architecture and Coptic burials (normally in pits), where $\mathrm{N} 2844$ "had possibly been pit and chamber" and N 2845 was "probably a Copt."

There are many examples of later burials intruding on earlier ones (e.g., $\mathrm{N} 2214,2215)$. One interesting example of an intrusion is found in $\mathrm{N} \mathrm{2143,} \mathrm{a}$ chamber tomb of indeterminate date. The entrance to the chamber had been blocked with bricks and fill. An oval pottery coffin had fallen through 
into the chamber from another burial. The oval pottery coffin was common at Naga ed-Deir in the Dynasty 3 tombs and perhaps Dynasty 4 tombs, as well, for example, in N 1640 and 1585 (Reisner 1908, 63-64), N 4371, 4718, 4749, 5105, 5302 (Mace 1909, 34-35, pls. 54-55), and N 544, 56o, 662, 644, and 588 (Reisner 1932, 15).

In general, the Coptic burials in $\mathrm{N} 2000$ and $\mathrm{N} 2500$ were not found in wooden coffins unless an older coffin happened to be in a particular tomb and was reused (e.g., N 2631). Mace's association of the earlier burials with coffins and the later burials as being without coffins is clear in his observation regarding $\mathrm{N} 2305$ in the Catalogue, that the tomb contained "remains of wooden coffin, so probably Dynasty 6-9" (page 107). For this reason, it has been assumed in this publication that all tombs that have evidence of a wooden coffin date to the First Intermediate Period/Middle Kingdom. Evidence of a coffin includes traces of wood or traces of paint from the coffin (e.g., 2104).

Besides not usually containing coffins, the Coptic burials are often easily identifiable due to the significant amount of linen wrappings and Coptic textiles that were preserved. Those burials typically included few, if any, manufactured artifacts, but accompanying the body were pieces of various plants, as well as salt. The First Intermediate Period/Middle Kingdom burials contained an array of ceramics, alabaster, beads, and other objects. The garments or wrappings typically did not survive, and there were no plant remains or salt associated with the body. A scarab that Mace dates to Dynasty 18 in a Coptic burial in $\mathrm{N} 2636$ seems to provide evidence of antiquarianism. (For other examples, see Johnson and Whitcomb 1989; Davies 2015.) The same may be said for a scarab reading Menkheperre found under Reisner's direction during the 1901 season in $\mathrm{N} 25 \mathrm{Ol}$.

As mentioned above, the key dating criterion for Mace was a coin from $\mathrm{N} 4511$ (Fig. 9.3). Dated in his manuscript to 529 or 53 O CE, the coin, in Mace's opinion, dates the Coptic burials in this cemetery "with some confidence ... to the latter half of the sixth century." He concedes, "Of course it would be possible for a coin to be kept for some time before being used in this way [i.e., being pierced and worn as a pendant], but the period would probably not exceed fifty years" (page 496). Given the evidence of the Dynasty 18 scarab found in the Coptic

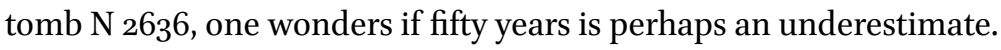

\section{7 This Publication of Cemeteries N 2000 and N 2500}

This publication serves three purposes. It brings to the public for the first time archaeological material that was excavated in the early twentieth century but 
was never published. It unites material from the site that is currently in the collections of two museums. Finally, the book brings together archaeological voices across time. Arthur C. Mace, the lead archaeologist at the site during the excavation of $\mathrm{N} 2000$ and $\mathrm{N} 2500$, left behind his field notes on individual cards and a draft of a manuscript for the publication of the Coptic tombs in this cemetery group. The data and drawings on his tomb cards have been rerecorded in the Catalogue of Tombs. His narrative, found in the Appendix, describes the site as a whole, the Coptic community as it existed in the area in his day, and his summary of the Coptic burials, the bodies, and the objects included with the burials. The authors' in this volume have added their voices to Mace's to provide a contemporary analysis of the objects.

Reisner advocated for large-scale excavation of a site rather than focusing on small areas because he required a range of materials wide enough to enable him to draw conclusions about the "development of civilization" (Reisner 1908, viii). He also stressed the importance of publishing final records of all findings in each grave rather than the "hasty publication" of annual archaeological reports with, as he saw it, their necessarily ever-changing hypotheses about the finds (Reisner 1908, viii). Our project will continue to follow Reisner's publication plan for these cemeteries with the important addition of Mace's manuscript.

The First Intermediate Period/Middle Kingdom burials contained a variety of goods. Those objects are described as follows: ceramics (Natasha Ayers, Gabriella diBattista, Brooke Norton), scarabs and seals (Emily Teeter), flints (Lisa Maher), small stone vessels (Virginia Emery), miscellaneous objects (Elizabeth Minor), and beads and pendants (Jolanda Bos, Vanessa Davies, Andrea Miloslavic, Jocelyn Simlick).

The Coptic burials often contained nothing in the way of grave goods that the excavators found. The bodies were, however, often enclosed in clothing and wraps with patterns and designs on them. Those textiles are described by Amandine Mérat. The wrapping of the bodies, which often included some sticks or other plant matter and a sprinkling of salt, are discussed by Jonathan Elias.

This volume poses two methodological questions of Reisner's work that will be answered in the documentary material. The first question is to understand the nature of the work that Reisner's team did in these two cemeteries. For example, one grave in particular ( $\mathrm{N} 2446)$ was quite well endowed, accounting for $50 \%$ of all of the cemetery's ceramic material that is in the collection of the Hearst Museum. Does that statistic reflect the ancient material or the excavators' practices? Was the burial particularly well appointed, but ultimately an anomaly in comparison with the cemetery's other burials? Was that burial excavated more thoroughly than other burials, or were more artifacts chosen from that burial to be shipped to the U.S. for analysis? 
The second question will explore why, in particular, the artifacts in the collection of the Hearst Museum were chosen by the excavators to be shipped off-site. The seemingly sporadic work in these cemeteries, which the first question will address, is reflected in the eclectic composition of the artifacts that Reisner chose to send to California. For example, the material in the Hearst Museum from cemetery $\mathrm{N}_{500}$ includes 85 flint objects of various types, and from cemeteries $\mathrm{N}$ 90o, $\mathrm{N} 7000, \mathrm{~N}_{3500}$, and $\mathrm{N}_{15} 00$, there are $47,47,37$, and 19 flint objects respectively. The collections from cemeteries $\mathrm{N} 2000$ and $\mathrm{N} 2500$ contain 2 flint objects each. Is this uneven distribution of material reflective of the finds in the burials, or might it relate to the excavation techniques or the particular interests of the excavation director?

This book aims to present material in the way that Reisner and Mace would have done, based on their reports of Naga ed-Deir excavations (Fig. o.19). The organization of material here thus purposefully aligns with their publications. Modern archaeological publications present material in a different way, ask different questions of the material, and tend to be more sensitive of the power imbalance internally, between excavation directors and field laborers, and externally, between the observing culture(s) and the culture observed. Recently, archaeologists and historians have taken steps to remedy the absence of names, narratives, and images of indigenous archaeologists in most early archaeological publications (for example, Quirke 2010; Riggs 2017). This welcome trend

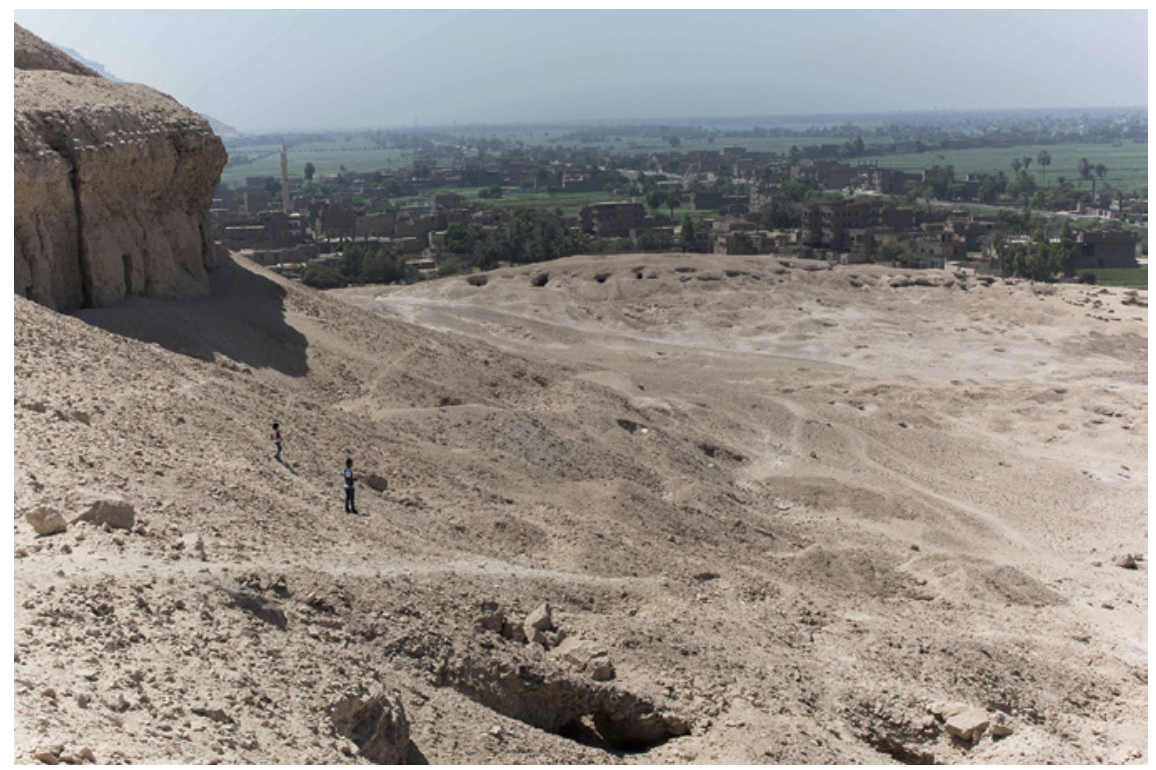

FIGURE 0.19 Looking south towards N 15 Oo with village in background PHOTO BY AYMAN DAMARANY 
acknowledges and attempts to correct the "inequalities and injustices" that "colonial-era archaeology helped create, reify, and reinforce" (Riggs 2017, 362).

Reisner was supportive of the people who worked for him in a way that was not entirely common in his day and yet was still largely constrained by the sociocultural limitations of colonial-era archaeology. In publications, Reisner often named and thanked his archaeological laborers, at least those who held leadership roles. His attitude in this regard caused him to sometimes be at odds with the culture of his contemporaries, as a tense exchange with archaeologist Clarence Fisher shows. In the exchange, Fisher disapprovingly referred to Reisner's "inexplicable devotion" to Egyptians, particularly those who worked for him (Doyon 2018, 188). Nonetheless, whatever "devotion" Reisner may have felt for his employees was expressed within certain social, cultural, and professional strictures (Doyon 2018, 185). For example, neither Reisner nor Mace included Egyptian members of the team in the analysis or interpretation of excavated material.

Reisner organized archaeological labor according to the model that Flinders Petrie developed. It was a model that reflected the Western ideal of an orderly and methodical scientific pursuit and also was rooted in hierarchical, colonial, and industrial systems. The (Western) excavation director apportions both excavated zone and (non-Western) laborers into discrete units, setting them to their task under his (because the Director was usually a man) surveilling eye (for this, see Schlanger 2010, 164-166, Fig. 9.2). In Reisner's case, the systems underpinning his archaeological work can be seen in his adherence to scientific method and in his description of his eleven groups of Egyptian workers at Naga ed-Deir, described above, as "gangs," a word that homogenizes workers and their labor. This volume tries to give attention to sociocultural questions beyond the excavated material and to give appropriate recognition to the Egyptians who worked with Reisner and Mace at Naga ed-Deir by naming the Egyptian archaeologists who worked at Naga ed-Deir (those whose names were found), by not reproducing photographs of uncovered human remains, and by noting the racist work of Grafton Elliot Smith. At the same time, this volume also acknowledges its own limitations in fully addressing these concerns.

Reisner's archaeological career spanned many historical periods at diverse sites ranging up and down the Nile River Valley. For him, one point about the site of Naga ed-Deir was that it highlighted the more important works of art, architecture, and handcrafts that were found in the vicinity of the Egyptian capital (Reisner 1932, 192). The authors in this volume present the material from Cemeteries $\mathrm{N} 2000$ and $\mathrm{N} 2500$ as testaments to lives lived in this region and as examples of carefully worked objects worthy of study on their own merits. 


\section{Bibliography}

Brovarski, E. 2018. Naga-ed-Dêr in the First Intermediate Period. Atlanta.

Challis, D. 2013. The Archaeology of Race: The Eugenic Ideas of Francis Galton and Flinders Petrie. London.

Davies, V. 2015. "Observations on Antiquities in Later Contexts." In A Cosmopolitan City: Muslims, Christians, and Jews in Old Cairo, edited by T. Vorderstrasse and T. Treptow, 85-92. оIMP 38. Chicago.

Doyon, W. 2018. "The History of Archaeology through the Eyes of Egyptians." In Unmasking Ideology in Imperial and Colonial Archaeology: Vocabulary, Symbols, and Legacy, edited by B. Effros and G. Lai, 173-200. Ideas, Debates, and Perspectives 8. Los Angeles.

Friedman, R. 1981. Spatial Distribution in a Predynastic Cemetery: Naga ed-Der 7000. MA thesis. University of California, Berkeley.

Gange, D. 2013. Dialogues with the Dead: Egyptology in British Culture and Religion, 1822-1922. Oxford.

Johnson, J. H. and D. Whitcomb. 1989. "A Royal Head from Luxor." In Essays in Ancient Civilization Presented to Helene J. Kantor, edited by A. Leonard, Jr., and B. Beyer Williams, $135^{-148 . ~ S A O C ~} 47$. Chicago.

Lane, E. W. 200o. Description of Egypt. Edited and with an introduction by J. Thompson. Cairo.

Lythgoe, A. M. 1965. The Predynastic Cemetery $N$ 7000, Naga ed-Der. Edited by D. Dunham. University of California Publications, Egyptian Archaeology 7. Berkeley.

Mace, A. C. 19o9. Early Dynastic Cemeteries of Naga-ed-Dêr, Part II. University of California Publications, Egyptian Archaeology 3. Leipzig.

Peck, C. N. 1958. Some Decorated Tombs of the First Intermediate Period at Naga Ed-Der. $\mathrm{PhD}$ diss. Brown University.

Quirke, S. 2010. Hidden Hands: Egyptian Workforces in Petrie Excavation Archives, 18801924. London.

Reisner, G. A. 1908. Early Dynastic Cemeteries of Naga-ed-Dêr, Part I. University of California Publications, Egyptian Archaeology 2. [Leipzig].

Reisner, G. A. 1932. A Provincial Cemetery of the Pyramid Age, Naga-ed-Dêr Part III. University of California Publications, Egyptian Archaeology 6. Berkeley.

Riggs, C. 2017. "Shouldering the Past: Photography, archaeology, and collective effort at the tomb of Tutankhamun." History of Science 55(3): 336-363.

Schlanger, N. 2010. "Manual and Intellectual Labour in Archaeology: Past and Present in Human Resource Management." In Unquiet Pasts: Risk Society, Lived Cultural Heritage, Re-designing Reflexivity, edited by S. Koerner and I. Russell, 161-171. London. 